University for Business and Technology in Kosovo

UBT Knowledge Center

UBT International Conference

2017 UBT International Conference

Oct 28th, 11:00 AM - 12:30 PM

\title{
Thinking styles through the elements of contemporary methods
}

Roland Sahatcija

Mediterranean University of Albania, rsahatcija@rogers.com

Ariel Ora

Carleton University, arieloraa@gmail.com

Anxhela Ferhataj

European University of Tirana

Follow this and additional works at: https://knowledgecenter.ubt-uni.net/conference

Part of the Education Commons

\section{Recommended Citation}

Sahatcija, Roland; Ora, Ariel; and Ferhataj, Anxhela, "Thinking styles through the elements of contemporary methods" (2017). UBT International Conference. 121.

https://knowledgecenter.ubt-uni.net/conference/2017/all-events/121

This Event is brought to you for free and open access by the Publication and Journals at UBT Knowledge Center. It has been accepted for inclusion in UBT International Conference by an authorized administrator of UBT Knowledge Center. For more information, please contact knowledge.center@ubt-uni.net. 


\title{
Thinking Styles through the Elements of Contemporary Teaching Methods
}

\author{
Roland Sahatcija $^{1 *}$, Ariel Ora ${ }^{2}$, and Anxhela Ferhataj ${ }^{3}$ \\ ${ }^{1}$ Department of Informatics, Mathematics and Support, Faculty of Economic \\ Sciences, Mediterranean University of Albania, Albania \\ ${ }^{2}$ Carleton University, Ottawa, Canada \\ ${ }^{3}$ European University of Tirana, Albania \\ rsahatcija@rogers.com
}

\begin{abstract}
In a fast-changing world, knowing one's strengths is a definite advantage. It is one's thinking style that provides such an edge. Knowing about thinking styles not only helps universities to be more effective and efficient, but also assists students in improving their academic performance.

The scope of this paper is to study the correlation that exists between thinking styles and the elements of contemporary teaching methods. Another objective of this research is analyzing the thinking styles of students. The study sample consists of 186 students of universities in Albania. The statistical analyses adopted in this study are: Pearson's correlation coefficient, the distribution table, and the One-Way ANOVA test. In order to analyze the data, SPSS 20 and JASP-8.0.1.2 have been used.

It ensues from the study that thinking styles affect two elements of contemporary teaching methods. Most students belong to the concrete-sequential thinking style. The element which students prefer the most is brainstorming. Further, the way in which the elements are assessed changes from one thinking style to the other.
\end{abstract}

Keywords: thinking style, concrete-sequential, concrete-random, abstract-sequential, abstract-random, elements of contemporary teaching methods

\section{Introduction}

Thinking differs from one person to the other. Every student reacts differently to situations [1]. Universities must strive to know students in order to offer the best to them. The appropriate teaching methodology definitely influences the development of skills in students. So, the combination of contemporary teaching methods in the teaching process has a positive impact in the development of new ideas from students [2]. As a result, students become more engaged and are more satisfied in university. The aim of this paper is the study of thinking styles and the correlation between the thinking style and the elements of contemporary teaching methods.

\section{Literature review}

Several studies have been conducted on the subject of the thinking style. The thinking style can be defined as the manner in which an individual applies their skills. Individuals apply different styles in order to utilize their skills. There are several methods for categorizing thinking styles 
[3]. Different researchers have organized thinking styles in groups [4, 5]. One of the researchers to have contributed in the field is Anthony Gregorc, who developed in 1984 the concept of the mind style. According to Gregorc (2017) mind styles are divided in two groups: perceptual abilities and ordering abilities. Perceptual abilities are divided into concrete (the five senses) and abstract (understanding ideas and qualities which cannot be seen). Ordering abilities are divided in sequential (organization of information in a linear and logical way) and random (organization of the information in blocks and in no particular order). These two groups are further combined into four categories: concrete-sequential, concrete-random, abstract-sequential, abstract-random. Students belonging to the first category prefer working in a structured environment, solo, follow procedures, and apply a logical order in organizing information. Students belonging to the second category, prefer taking risks, produce experiments, follow their intuition and solve problems independently. Students in the third category, use logic to solve problems, wants their voice heard and need to analyze the situation before making a decision. Students in the fourth category, prefer to listen to others, have good working relationships with colleagues, focus on day-to-day work problems and work well in a team. This is the categorization that will be adopted in this study. Technological advances have had an impact on education. More and more elements of e-learning are being implemented into study programs [6]. The utilization of contemporary teaching methods influences the creation of new skills, the improvement of academic performance, and development of the student's personality [7]. Al Maghraby and Alshami (2013) arrived at the conclusion that the correlation between teaching methods and learning styles are insignificant. In addition, most students prefer the concrete-sequential thinking style and the training of the elements of teaching methods.

The research questions are:

1. How are students classified based on thinking style?

2. Which element of contemporary teaching methods is most favored by students?

3. Do thinking styles have an impact on students' preferences for elements of contemporary teaching methods?

Research hypotheses are:

- H1: Students rate the same all elements of contemporary teaching methods independent of thinking styles $(\alpha=0.05)$.

This conceptual model is based on conclusion of the literature review:

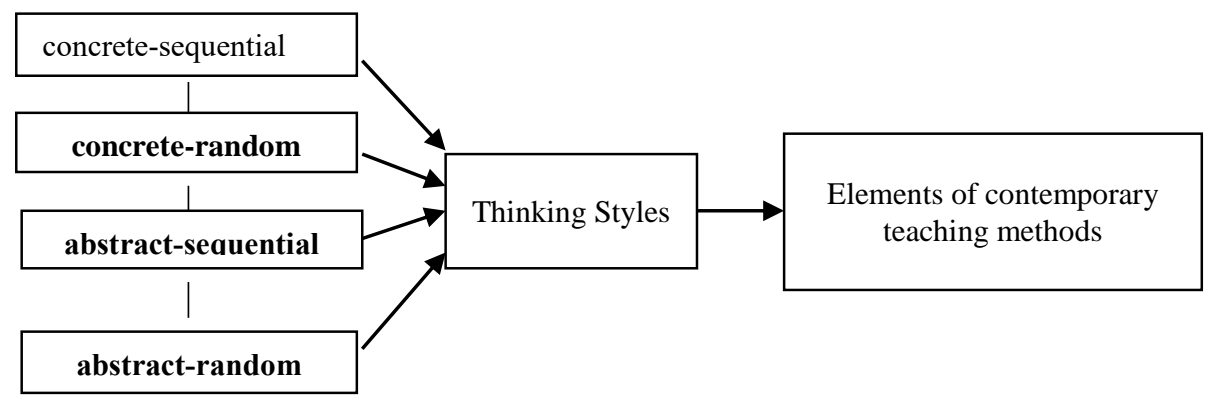

\section{Methodology}

The methods applied in this research paper are the descriptive method and the research analysis is quantitative. For this study the research instrument utilized was the questionnaire. [8,9]. The questionnaire covers two aspects: thinking styles and elements of contemporary teaching methods. In order to evaluate the questions a 5-point Likert scale was employed with options 
ranging from "Not at all Important" to "Extremely Important". The surveys were distributed online during the second semester of the 2016-2017 academic year. The study sample consists of 186 Albanian university students. The rate of return for the response was 90\% (168/186). Students come from different levels and study areas. Analyses were conducted with SPSS 20 and JASP-0.8.1.2. Survey data are valid for the purpose of the analysis because Cronbach's $\alpha$ reliability coefficient is 0.851 .

Table 1: Reliability Coefficient

\begin{tabular}{lc}
\hline & Cronbach's $\boldsymbol{\alpha}$ \\
\hline scale & 0.851 \\
\hline
\end{tabular}

Note. Of the observations, 168 were used, 0 were excluded listwise, and 168 were provided.

\section{Empirical Analysis}

This part of the study will deal with the statistical analysis of the study data.

How are students classified based on thinking style?

Table 2 provides information on student thinking styles. Most students belong to the concretesequential category or $41 \%$. The other styles are also preferred. Students have the same preference for the concrete-random and abstract-sequential styles, or $20.2 \%$ for each group respectively. While $18.5 \%$ of students prefer the abstract-random style. The values are graphically presented in Graph 1 .

Table 2: Thinking Styles

\begin{tabular}{lclcc}
\hline & Frequency & Percent & Valid Percent & $\begin{array}{l}\text { Cumulative } \\
\text { Percent }\end{array}$ \\
\hline concrete-sequential & 69 & 41.1 & 41.1 & 41.1 \\
concrete random & 34 & 20.2 & 20.2 & 61.3 \\
abstract-sequential & 34 & 20.2 & 20.2 & 81.5 \\
abstract-random & 31 & 18.5 & 18.5 & 100.0 \\
Total & 168 & 100.0 & 100.0 & \\
& & & & \\
\hline
\end{tabular}

a concrete-sequential $\square$ concrete random $\square$ abstract-sequential $\square$ abstract-random

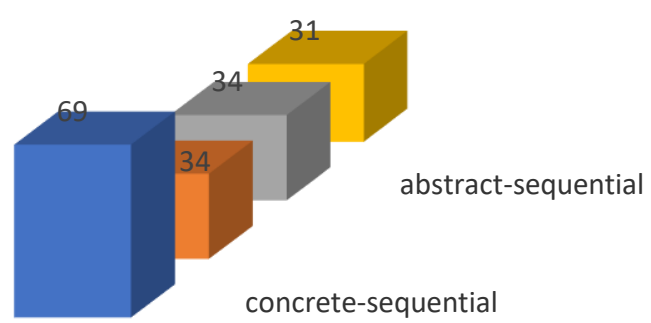

\section{Graph 1: Thinking Styles}

Which element of contemporary teaching methods is most favored by students?

Most favored element by students is brainstorming with an average value of 3.714 (Table 3). Research project development ranks second most important, with an average value of 3.690 and 
third subject analysis with an average value of 3.631. Whereas preferences according to each thinking style are presented in Table 4.

Table 3: Elements of contemporary teaching methods

\begin{tabular}{lcccc}
\hline & N & Mean & SD & SE \\
\hline Subject analysis & 168.0 & 3.631 & 0.837 & 0.065 \\
Brainstorming & 168.0 & $\mathbf{3 . 7 1 4}$ & 0.883 & 0.068 \\
Research project development & 168.0 & 3.690 & 0.781 & 0.060
\end{tabular}

Table 4: Elements of contemporary teaching methods

\begin{tabular}{llcccc}
\hline & & N & Mean & SD & SE \\
\hline \multirow{5}{*}{ concrete-sequential } & Subject Analysis & 69 & 3.90 & 0.877 & 0.106 \\
& Brainstorming & 69 & 3.70 & 0.845 & 0.102 \\
& $\begin{array}{l}\text { Theory-Practice } \\
\text { Integration Lecture }\end{array}$ & 69 & 3.68 & 0.962 & 0.116 \\
& Research Project & 34 & 3.82 & 0.758 & 0.130 \\
concrete random & Development & & & & \\
& Case Study Analysis & 34 & 3.76 & 0.855 & 0.147 \\
& Class Discussion & 34 & 3.62 & 0.739 & 0.127 \\
& Theory-Practice & 34 & 3.62 & 0.779 & 0.134 \\
& Integration Lecture & & & & \\
abstract-sequential & Research Project & 34 & 3.62 & 0.739 & 0.127 \\
& Development & 34 & 3.62 & 0.652 & 0.112 \\
& Brainstorming & 31 & 3.81 & 0.833 & 0.150 \\
Brainstorming & Class Discussion & 31 & 4.00 & 0.775 & 0.139 \\
& Case Study Analysis & 31 & 3.94 & 0.772 & 0.139
\end{tabular}

Do thinking styles have an impact on students' preferences for elements of contemporary teaching methods?

According to the data from Table 5, thinking style has an impact only on two elements. There exists a strong positive correlation between thinking styles and the construction of a questionnaire with correlation coefficient $=0.213$ and $\mathrm{p}=0.006$. The independent variable has an impact on the dependent variable. Both variables move in the same direction. Case study analysis has a significant statistical correlation with thinking styles with correlation coefficient $=0.171$ and $\mathrm{p}=0.027$. An increase in the independent variable has an impact on an increase in the dependent variable. Whereas between the other elements and the thinking style there exist insignificant statistical correlations. From this analysis is derived that thinking styles have an impact only on two of the elements of contemporary teaching methods. 
Table 5: Pearson Correlations and One-Way ANOVA

\begin{tabular}{|c|c|c|c|c|}
\hline & rrson Correl & & One-Way & \\
\hline & Think & Style & $\mathbf{F}$ & Sig \\
\hline & $\begin{array}{c}\text { Pearson's } \\
\mathbf{r}\end{array}$ & p-value & & \\
\hline E-learning & -0.099 & 0.201 & 1.482 & .221 \\
\hline Discussion Groups & 0.048 & 0.539 & .847 & .470 \\
\hline Subject analysis & -0.044 & 0.575 & .172 & .915 \\
\hline Case study analysis & $0.171 *$ & 0.027 & 2.420 & .068 \\
\hline Survey analysis & 0.023 & 0.769 & 1.153 & .330 \\
\hline Focus groups & -0.027 & 0.73 & .108 & .955 \\
\hline Class discussion & 0.069 & 0.371 & 5.797 & .001 \\
\hline Public lecture & -0.072 & 0.355 & .660 & .578 \\
\hline $\begin{array}{l}\text { Theory-practice } \\
\text { Integration Lecture }\end{array}$ & -0.024 & 0.76 & .541 & .655 \\
\hline Questionnaire building & $0.213 * *$ & 0.006 & 3.055 & .030 \\
\hline $\begin{array}{l}\text { Class-project } \\
\text { development }\end{array}$ & 0.087 & 0.263 & 1.204 & .310 \\
\hline $\begin{array}{ll}\text { In-class } & \text { student } \\
\text { engagement } & \end{array}$ & -0.091 & 0.239 & 1.485 & .221 \\
\hline $\begin{array}{l}\text { Multimedia } \\
\text { implementation }\end{array}$ & -0.084 & 0.276 & .440 & .725 \\
\hline Study Group & -0.092 & 0.234 & 2.072 & .106 \\
\hline $\begin{array}{l}\text { Research project } \\
\text { development }\end{array}$ & 0.029 & 0.71 & .573 & .634 \\
\hline $\begin{array}{l}\text { Tape-recording } \\
\text { conversations }\end{array}$ & 0.021 & 0.787 & .238 & .870 \\
\hline 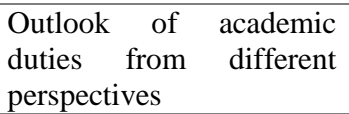 & -0.078 & 0.317 & .520 & .669 \\
\hline Brainstorming & -0.06 & 0.437 & 3.275 & .023 \\
\hline $\begin{array}{l}\text { Applying theory in } \\
\text { practice }\end{array}$ & -0.081 & 0.298 & 1.453 & .230 \\
\hline Using additional readings & 0.066 & 0.397 & 1.250 & .294 \\
\hline
\end{tabular}

$* \mathrm{p}<.05, * * \mathrm{p}<.01, * * * \mathrm{p}<.001$

${ }^{\mathrm{a}}$ Levene's test is significant $(\mathrm{p}<.05)$, suggesting a violation of the equal variance assumption

H1: Students rate the same all elements of contemporary teaching methods independent of thinking styles $(\alpha=0.05)$.

To prove the hypothesis One-Way Anova is utilized at Table 5. Sig value is analyzed, if smaller than $\alpha=0.05$ there exist differences and the opposite. The analysis demonstrates that students' rating differs with respect to these elements: class discussions, questionnaire building and brainstorming. Thinking styles have an impact on the rating of the elements. Students belonging 
to different thinking categories rate differently. Although for most elements the values do not change, hypothesis $\mathrm{H} 1$ is not accepted because there exist differences in values for three elements.

\section{Conclusions and Recommendations}

Most frequently utilized thinking style in students is concrete-sequential. The other styles are also utilized by students. Most valued elements by students are three: first, brainstorming, second, research project development and third, subject analysis. Thinking styles have an impact on only two elements of contemporary teaching methods. Significant statistical correlations occur between thinking styles and questionnaire building with correlation $=0.213$ and $p=0.006$ and thinking styles and case study analysis with correlation coefficient $=0.171$ and $p=0.027$. The rating of elements of contemporary teaching methods by students change according to thinking styles. The study conclusions recommend that universities utilize different elements in teaching. They also need to apply similar teaching methods in order to discover the students' thinking styles, so that they can offer the appropriate teaching methods that will benefit every student.

\section{Reference}

[1] T. Brown, T. Cosgriff and G. French, " Learning style preferences of occupational therapy, physiotherapy and speech pathology students: A comparative study," The Internet Journal of Allied Health Sciences and Practice, vol. 6, pp. 1-12, 2008.

[2] S. Jones, C. Johnson-Yale, F. S. Perez and J. Schuler, "The Internet landscape in college," Yearbook of the National Society for the Study of Education, vol. 106, no. 2, pp. 39-51, 2007.

[3] R. J. Sternberg, E. L. Grigorenko and L.-F. Zhang, "Styles of learning and thinking matter in instruction and assessment," Perspectives on Psychological Science, vol. 3, no. 6, pp. 486-506, 2008.

[4] R. J. Sternberg, Thinking styles, New York: Cambridge University Press, 1997.

[5] L.-F. Zhang and R. J. Sternberg, "A threefold model of intellectual styles," Educational Psychology Review, vol. 17, no. 1, pp. 1-53, 2005.

[6] V. Toktarova, "Pedagogical Management of Learning Activities of Students in the Electronic Educational Environment of the University: A Differentiated Approach," International Education Studies, vol. 8, no. 5, pp. 205-212, 2015.

[7] A. J. Smith, C. Cavanaugh, J. Jones, J. Venn and W. Wilson, "Influence of learning style on instructional multimedia effects on graduate student cognitive and psychomotor performance," J Allied Health, vol. 35, p. 182-203, 2006.

[8] A. F. Gregorc, "Mind Styles - Anthony Gregorc," 13 September 2017. [Online]. Available: http://web.cortland.edu/andersmd/learning/gregorc.htm.

[9] M. A. Al Maghraby and A. M. Alshami, "Learning style and teaching method preferences of Saudi students of physical therapy," Journal of Family and Community Medicine, vol. 20, no. 3, pp. 192-197, 2013. 